\title{
Merombak Struktur, Membentuk Kultur \\ (Studi Pemikiran Siti Musdah Mulia)
}

\author{
Eka Suriansyah \\ IAIN Palangka Raya \\ eksasmart@gmail.com
}

\begin{abstract}
Law is a structure in society that can lead to the formation of a culture. The formation of culture is closely related to the legal system existing in society. Similarly, marriage culture that occurs in society is the result of the formation of a legal structure. In Indonesia, the legal structure of marriage is based on the Marriage Act No. 1 year 1974 and Presidential Instruction No. 1 year 1991 on the Compilation of Islamic Law. These two legal products are controlling the pattern of marriage rules in Indonesia. As time goes by, both products require refinement because of the emergence of the existing of various cases. For example, unregistered marriage that is considered by some people to be the legality of affair where it is due to lack of firmness in the mechanism of marriage recording. Responding to this phenomenon, Musdah Mulia, as an academician, tried to formulate Counter Legal Draft of Compilation of Islamic Law as a form of participating in solving community problems which gradually became a negative culture for the nation.
\end{abstract}

Keywords: Legal structure, Culture, Marriage and Musdah Mulia

\section{A. Pendahuluan}

Manusia sebagai makhluk sosial yang bermasyarakat tidak bisa hidup tanpa ada hukum, apapun nama atau sebutannya. Ia yang mengatur pola pergaulan hidup di masyarakat. Masyarakat dan hukum laksana hubungan erat antara ikan dan air yang berbeda tetapi selalu menyatu. ${ }^{1}$ Seorang filosofi Romawi, Celcius menegaskan ubi societas ibi ius. Maksudnya di mana ada masyarakat di situlah

\footnotetext{
${ }^{1}$ Muhammad Amin Summa, Hukum Keluarga Islam Di Dunia Islam (Jakarta: Rajawali Pers, 2004), 2.
} 
ada hukum. ${ }^{2}$ Hukum sebagai sebuah struktur yang mengatur pola masyarakat hingga membentuk sebuah kultur.

Kultur keluarga Islam yang ada di Indonesia sangatlah dipengaruhi oleh struktur hukum keluarga yang berlaku. Di Indonesia hukum keluarga yang didalamnya mencakup tentang perkawinan serta perceraian di atur dalam sistem struktur perudang-undangan tentang Perkawinan dalam UU No. 1 tahun 1979 tentang Undang-Undang Perkawinan dan selanjutnya secara khusus untuk umat Islam di atur dalam Inpres No. 01 tahun 1991 tentang Kompilasi Hukum Islam. Struktur hukum inilah yang mengatur pola masyarakat Islam dalam tata perkawinan serta perceraian ataupun akibat yang lahir dari keduanya.

Berbagai kasus dalam ranah keluarga seperti perceraian, pernikahan dini, poligami yang muncul di masyarakat, seolah tidak pernah habis. Bahkan lambat laun menjadi sebuah kultur yang dianggap lumrah. Istilah selingkuh, nikah siri, nikah usia muda, perceraian perlahan menjadi istilah yang lazim bukan sesuatu yang tabu. Sederatan kasus perceraian dikalangan artis, perselingkuhan yang mengatas namakan poligami, pernikahan di bawah umur, menggambarkan lemahnya sistem struktur hukum keluarga Islam yang ada di Indonesia. Lemahnya aturan pencatatan perkawinan memberikan dampak pada maraknya nikah di bawah tangan atau nikah sirri dan longgarnya batasan umur menjembatani pernikahan usia muda.

Realitas sosial yang dihadapi sekarang, tidaklah serta merta harus dibiarkan tanpa solusi. Adalah seorang pemikir perempuan; Musdah Mulia, mencoba memberikan solusi terhadap problematika yang sampai saat ini masih menjamur di masyarakat. Akar permasalahnnya adalah pada struktur hukum yang berimbas pada kultur sosial. Lemahnya struktur hukum keluarga Islam yang diatur

${ }^{2}$ F. Isjawara, Pengantar Ilmu Politik (Jakarta: Bina Cipta, 1992), 79. 
dalam UUP ataupun KHI mengharuskannya dekonstruksi beberapa pasal guna menyelesaikan permasalahan tersebut. Berdasarkan data Pengadilan Agama di beberapa daerah di Indonesia mencatat pasangan yang menikah antara usia 20-25 tahun $50 \%$ mengalami perceraian. Rata-rata alasannya perselingkuhan dan faktor ekonomi. Bahkan Indonesia menurut data statistik UNICEF adalah salah satu negara tertinggi pernikahan usia anak di kawasan Asia Timur dan Pasifik. ${ }^{3}$

Membincangkan Musdah Mulia selalu diidentikkan dengan sosok kontroversial. Penghalal Homo Sexsual, Tokoh Nikah Beda Agama, Sesat dan banyak lagi istilah-istilah yang di sematkan padanya oleh kelompok yang menolak ide-idenya. Berbalik 180 derajat dari istilah tersebut, Sang Pembaharu, Pejuang Perempuan, Pembela Hak Asasi Manusia adalah istilah apresiatif dari kelompok yang memahami ide briliant-nya. Istilah itu kemudian memposisikannya sebagai seorang yang multi face. Terlepas dari dua sudut pandang tersebut, idenya terkait pembaharuan Kompilasi Hukum Islam adalah bagian dari solusi permasalahan keluarga yang sekarang seolah-olah yang tidak pernah habis.

Tanpa bermaksud mengesampingkan berbagai opini yang sudah muncul dan berkembang terhadapnya, tulisan ini membahas dari sudut pandang Siti Musdah Mulia sebagai seorang tokoh pemikir Islam Kontemporer di Indonesia yang mencoba memberikan kontribusi atas permasalahan sosial bangsa dengan rekontruksi definisi perkawinan dalam UUP serta beberapa pasal dalam Kompilasi Hukum Islam yang dijadikan landasan konstitusi perkawinan di Indonesia.

3 UNICEF, Kemajuan Yang Tertunda: Analisis Data Perkawinan Usia Anak Di Indonesia (Jakarta: Badan Pusat Statistik, 2015), 1. 


\section{B. Kajian Pustaka}

Tulisan ini memakai rujukan beberapa buku yang terkait dengan judul tulisan ini di antaranya Djohan Effendi, Pembaruan Tanpa Membongkar Tradisi, John L Esposito, Women in Muslim Family Law dan beberapa tulisan lain yang terkait judul artikel ini.

\section{Metode Penelitian}

Metode yang dipergunakan dalam tulisan ini adalah metode desktiptif analitis dengan model library research (penelitian kepustakaan) yakni menggunakan beberapa sumber untuk mengkaji tulisan yang terkait dengan judul tulisan ini yang kemudian dianalisa dan ditulis berdasarkan hasil penganalisaan. Tulisan ini tentu merujuk kepada tulisan John L. Esposito, Women in Muslim Family Law sebagai sumber utama serta tulisan-tulisan lain yang mendukung tulisan ini.

\section{Pembahasan}

\section{Biografi Siti Musdah Mulia ${ }^{4}$}

Sikerudung Putih dari Selatan adalah julukan yang diberikan teman dekatnya; Marwan Saridjo, kepada Siti Musdah Mulia saat duduk di SMA Datumuseng menjadi bintang dengan kerudung putihnya. ${ }^{5}$ Dia lahir di Bone, Sulawesi Selatan, 3 Maret 1959. Menikah pada tahun 1984 dengan Prof. Dr. Ahmad Thib Raya, MA; Guru Besar Pascasarjana UIN Syarif Hidayatullah Jakarta.

Musdah Mulia adalah Peneliti bidang Keagamaan; Dosen Pascasarjana UIN Syarif Hidayatullah Jakarta dalam bidang Sejarah dan Pemikiran Keislaman.

\footnotetext{
${ }^{4}$ Beni Setiawan, "Menggugat Poligami; Studi Atas Pemikiran Musdah Mulia," El-Mashlahah 3, no. 2 (2013): 95-97.

5 Marwan Saridjo, Cak Nur: Di Antara Sarung Dan Dasi Dan Musdah Mulia Tetap Berjilbab (Jakarta: Yayasan Ngali Aksara dan Penamadani, 2005), 71.
} 
Aktivis organisasi yang menekuni isu-isu demokrasi, HAM, jender dan pluralisme. Dia perempuan pertama memenangkan lomba Penulisan Karya Ilmiah Tingkat Mahasiswa IAIN se-Indonesia (1980). Perempuan pertama terpilih sebagai "doktor terbaik" IAIN Syarif Hidayatullah, Jakarta (1997) dengan disertasi berjudul Negara Islam: Pemikiran Husain Haikal. Dia pula perempuan pertama dikukuhkan LIPI (Lembaga Ilmu Pengetahuan Indonesia) sebagai Profesor Riset di lingkungan Departemen Agama (1999) dengan Pidato Pengukuhan berjudul Potret Perempuan dalam Lektur Agama.

Pendidikan formalnya dimulai dari SD di Surabaya (tamat 1969); Pesantren As'adiyah, Sengkang, Sulawesi Selatan (tamat 1973); SMA Perguruan Islam Datumuseng, Makasar (tamat 1974). Fakultas Syari'ah Perguruan As'adiyah (tidak tamat). Menyelesaikan program Sarjana Muda Jurusan Dakwah, Fakultas Ushuluddin, Universitas Muslim Indonesia (UMI) Makasar (1980); Program S1 Jurusan Bahasa dan Sastra Arab, Fakultas Adab, IAIN Alaudin, Makasar (1982); Program S2 Bidang Sejarah Pemikiran Islam, UIN Syarif Hidayatullah, Jakarta (1992); dan Program S3 Bidang Pemikiran Politik Islam di UIN Syarif Hidayatullah, Jakarta (1997), sebelumnya melakukan penelitian disertasi di Kairo, Mesir (1994).

Pendidikan non-formal antara lain: Kursus Singkat mengenai Islam dan Civil Society di Universitas Melbourne, Australia. (1998); Kursus Singkat Pendidikan HAM di Universitas Chulalongkorn, Thailand (2000); Kursus Singkat Advokasi Penegakan Demokrasi (International Visitor Program) di Amerika Serikat (2000); Kursus Singkat Manajemen Pendidikan dan Kepemimpinan di Universitas George Mason, Virginia, Amerika Serikat (2001); Kursus Singkat Pendidikan Alternatif di Universitas Lund, Swedia (2001); Kursus Singkat Manajemen Pendidikan dan Kepemimpinan Perempuan di Bangladesh 
Institute of Administration and Management (BIAM), Dhaka, Bangladesh (2002); International Leadership Visitor Program, US Departement of State, Washington (2007).

Pengalamannya dalam bidang pendidikan dan penelitian dimulai sebagai Dosen Luar Biasa di IAIN Alaudin, Makasar (1982-1989); Dosen Luar Biasa di UMI, Makasar (1982-1989); Dosen Luar Biasa di Univ. Satria, Makasar (19851989); Peneliti pada Balai Penelitian Lektur Agama, Depag, Makasar (19851989); Peneliti pada Balitbang Departemen Agama Pusat, Jakarta (1990sekarang); Dosen Institut Ilmu-Ilmu Al-Qur'an, Jakarta (1997-1999); Direktur Perguruan Al-Wathoniyah Pusat, Jakarta (1995-2005); Dosen Pascasarjana UIN, Jakarta (1997- sekarang); Visiting Profesor di EHESS, Paris, Perancis (2006). Pengalamannya dalam Birokrasi Organisasi Pemerintah (GO), antara lain Kepala Balai Penelitian Agama dan Kemasyarakatan Departemen Agama, Jakarta (19992000); Staf Ahli Menteri Negara Urusan Hak Asasi Manusia (HAM) Bidang Pencegahan Diskriminasi dan Perlindungan Minoritas (2000-2001); Tim Ahli Menteri Tenaga Kerja R.I. (2000-2001); Staf Ahli Menteri Agama R.I Bidang Pembinaan Hubungan Organisasi Keagamaan Internasional (2001-2007).

Pengalaman jabatan dalam Organisasi Non-pemerintah (NGO), antara lain Wakil Ketua KNPI Sul-Sel (1982-1986) Ketua Wilayah IPPNU Sul-Sel (19791982); Ketua Wilayah Fatayat NU Sul-Sel (1983-1989); Ketua PP. Fatayat NU (1990-2000); Wakil Sekjen PP. Muslimat NU (2000-2005); Anggota Dewan Ahli Koalisi Perempuan Indonesia (1999-2003); Ketua Forum Dialog Pemuka Agama Mengenai Kekerasan Terhadap Perempuan (1998-2001); Ketua I (MAAI) AlMajelis al-Alami lil-Alimat al-Muslimat Indonesia (2001-2003); Anggota Forum Komunikasi Umat Beragama (FKUB) DKI, Jakarta (2000-2005); Ketua Komisi Pengkajian MUI: Majelis Ulama Indonesia (2000-2005); dan Ketua Panah Gender 
dan Remaja Perhimpunan Keluarga Berencana Indonesia (2001-2006); Ketua Dewan Pakar Korps Perempuan Majelis Dakwah Islamiyah (1997-sekarang); Dewan Pakar Koalisi Perempuan Indonesia (2003-2007); Dewan Pakar Lembaga Bantuan Hukum APIK (2006-2009) Pendiri Lembaga Kajian Agama dan Gender (sejak 1998); Pendiri/Ketua Umum ICRP (Indonesian Conference On Religion and Peace) sampai sekarang. Dan sekarang sebagai Direktur Eksekutif Mega Institut.

Karya-karya yang sudah dihasilkannya Pangkal Penguasaan Bahasa Arab, Mediatama, (1989); Anotasi Buku Islam Kontemporer (2000); Poligami Dalam Pandangan Islam, LKAJ (2000); Kesetaraan dan Keadilan Gender: Perspektif Islam, Departemen Agama (2001); Pedoman Dakwah Muballighat (2000); Analisis Kebijakan Publik (2002); Meretas Jalan Awal Hidup Manusia: Modul Pelatihan Hak-Hak Reproduksi (2002); Seluk-Beluk Ibadah Dalam Islam (2002). Negara Islam: Pemikiran Politik Haikal, Paramadina, Jakarta (2000); Islam Menggugat Poligami, Gramedia, Jakarta (2004), Perempuan dan Politik, Gramedia, Jakarta (2005); Muslimah Reformis: Perempuan Pembaru Keagamaan, Mizan, Bandung, (2005); Islam and Violence Against Women, LKAJ, Jakarta (2006); Islam dan Inspirasi Kesetaraan Gender, Kibar, Yogyakarta (2007): Menuju Kemandirian Politik Perempuan: Upaya Mengakhiri Depotisme Perempuan di Indonesia, Kibar, Yogyakarta (2008): Ia juga menulis buku bersama Anik Farida, Poligami: 'Budaya Bisu' yang Merendahkan Martabat Perempuan, Kibar, Yogyakarta (2007). Sekarang sedang menyelesaikan buku Islam dan Perkawinan.

Tidak hanya menulis buku, ia juga menulis puluhan entri dalam Ensiklopedi Islam (1993), Ensiklopedi Hukum Islam (1997), dan Ensiklopedi AlQur'an (2000). Menulis sejumlah artikel dengan tema: Keislaman, Agama dan 
Perdamaian, Demokrasi, Civil Society, Gender, HAM, dan Pluralisme yang disajikan dalam berbagai forum ilmiah, baik di dalam maupun luar negeri.

\section{Konfigurasi Pemikiran Siti Musdah Mulia}

Nama Siti Musdah Mulia mulai dikenal luas masyarakat Indonesia karena keberaniannya menjadi pemimpin dalam melakukan pembaruan terhadap Kompilasi Hukum Islam, yang menimbulkan pro dan kontra. Namanya semakin luas dikenal dalam media massa setelah Majalah Tempo menganugerahinya sebagai People of Year pada tahun $2004 .^{6}$

Pemikiran Siti Musdah Mulia sangat kentara dipengaruhi oleh gerakan postmodernisme. Ia mengaku dalam hal keagamaan banyak dipengaruhi dan menaruh hormat pada pemikiran Harun Nasution dan Nurcholish Madjid. Dan dalam hal gender ia mengaku banyak dipengaruhi oleh Feminis Muslim seperti Fatimah Mernissi, Nawal Sadawi, Abdullahi an-Naim, dan Qasim Amin ${ }^{7}$

Elaborasi dari para tokoh yang mempengaruhinya, hingga pemikirannya berkutat pada pusaran isu-isu demokrasi, hak asasi manusia, gender dan pluralisme. Ide-idenya tersebut tersebar di berbagai karya-karyanya. Seperti Islam dan Inspirasi Kesetaraan Gender, Muslimah Reformasi; Perempuan Pembaharu Bangsa dan magnum opus kontroversialnya Counter Legal Drafting (CLD) KHI tahun 2004. Mengkaji CLD KHI -yang ia masuk sebagai ketua tim perumusnyamerupakan pintu masuk dalam memahami ide-ide pembaharuannya tentang Islam di Indonesia.

\footnotetext{
6 "Siti Musdah Mulia," n.d., http://www.prismajurnal.com/biodata.php?id=2ac22c0e-53a0-11e3a6cc-429e1b0bc2fa.

${ }^{7}$ Beni Setiawan, ",Menggugat Poligami; Studi Atas Pemikiran Musdah Mulia," El-Mashlahah 3, no. 2 (2013): 95-97.
} 


\section{CLD KHI; Sebuah Tawaran Rekonstruksi Struktur}

Perkembangan pemikiran hukum keluarga Islam di Indonesia sejak diundangkannya Undang-undang No. 1 tahun 1974 tentang perkawinan, pada tahun 1974 sampai tahun 2004 belum menunjukkan tingkat pergumulan yang dinamis. ${ }^{8}$ Dalam kurun waktu 30 tahun sejak Undang-undang perkawinan mulai diberlakukan, baru pada tahun 1991 muncul gagasan inovatif sebagai babak baru dalam sejarah perkembangan hukum keluarga Islam untuk dijadikan sebagai sumber hukum resmi, sebagai pedoman dalam menyelesaikan sengketa hukum antara pemeluk agama Islam di Pengadilan Agama yang dituangkan dalam Intruksi Presiden (Inpres) No. 1 tahun 1991 tentang Kompilasi Hukum Islam selanjutnya di singkat dengan KHI. Sejak lahirnya KHI pada tahun 1991, baru tahun 2004 muncul gagasan baru untuk memperbaharui materi Kompilasi Hukum Islam yang disusun oleh Tim Pengarusutamaan Gender Departemen Agama RI dalam bentuk Counter Legal Draft Kompilasi Hukum Islam.

Kompilasi Hukum Islam sejatinya adalah legalisasi Hukum Islam di Indonesia. Karena materi-materi hukum Islam sudah diintegrasikan dalam bahasa hukum hingga ia tidak muncul berwajahkan hukum Islam an sich. ${ }^{9}$ Siti Musdah Mulia berpendapat pembaharuan hukum Islam formal di Indonesia harus di mulai dari KHI dengan minimal empat alasan. Pertama, KHI dipandang sebagai jantung syariat atau inti ajaran Islam sehingga menjadi rujukan nilai di masyarakat. Kedua, KHI merupakan panduan hukum hakim agama di Pengadilan Agama dalam memutuskan perkara-perkara keluarga, khususnya di bidang perkawinan. Ketiga, upaya mengeliminasi semua bentuk diskriminasi terhadap

\footnotetext{
${ }^{8}$ Ridwan, Membongkar Fiqh Negara: Wacana Keadilan Gender Dalam Hukum Keluarga Islam (Yogyakarta: Unggun Religi, 2005), 139.

${ }^{9}$ Siti Musdah Mulia, Muslimah Reformasi; Perempuan Pembaru Keagamaan (Bandung: Mizan, 2005), 380.
} 
perempuan harus di mulai dari keluarga. Sebab, keluarga yang katanya merupakan wilayah yang paling aman itu justru paling banyak merekam kasus-kasus kekerasan dalam rumah tangga (domestic violence). Keempat, sejumlah pasal dalam KHI berseberangan dengan undang-undang baru, seperti Amandemen UUD 1945, UU No. 7 tentang Rativikasi CEDAW (The Convention on The Elimination of All Form Discrimination Agianst Women) adalah instrumen standar internasional menetapkan persamaan hak antara laki-laki dan perempuan yang diadopsi oleh PBB pada tahun 1979 dan mulai berlaku pada tanggal 3 Desember 1981) dan UU No. 39 Tahun $1999 .{ }^{10}$

Landasan epistemologis dalam melakukan pembaharuan pada KHI berlandaskan pada semangat upaya pembumian hukum Islam yang sesuai dengan kehidupan demokrasi dan mencerminkan karakter genuine kebudayaan Indonesia. Cita-cita dasar dari nilai pembaharuannya adalah semua warga negara mempunyai kedudukan yang sama dan memperoleh perlakuan yang adil, kaum minoritas dan perempuan dilindungi dan dijamin hak-haknya secara setara.

Adapun landasan metodologis yang digunakan dalam merumuskannya menggunakan teori maqashid syari'ah. Secara teknis dalam perumusannya merevitalisasi bangunan ushul fiqh klasik yang dirasa masih literalistik dalam mendekati persoalan hukum sehingga lebih berorientasi pada pencarian kebenaran normatif. Dari sini ada perombakan kerangka paradikmatik ushul fiqh lama dari paradigma teosentris ke antroposentris. Oleh sebab itu prinsip dasar yang dipegangi dalam memahami nash adalah menempatkan nash sebagai cita-cita etikmoral dari sebuah ayat dan bukan legislasi-spesifik atau formulasi-literalistik. Berpijak dari bangunan metodologis tersebut serta menjawab realitas sosial

${ }^{10}$ Siti Musdah Mulia, Islam Dan Inspirasi Kesetaraan Gender (Yogyakarta: Kibar Press, 2007), 166. 
maraknya permasalahn keluarga di Indonesia , maka dekonstruksi enam isu-isu krusial dalam UU Perkawinan ataupun KHI merupakan sebuah keharusan, karena merupakan sebuah struktur yang sangat berpengaruh dalam membangun dan mencipakan kultur yang berkeadilan.

\section{a. Definisi Perkawinan}

Perkawinan dalam Undang Undang Perkawinan adalah ikatan lahir batin antara seorang pria dengan seorang wanita sebagai suami isteri dengan tujuan membentuk keluarga, rumah tangga yang bahagia dan kekal berdasarkan Ketuhanan Yang Maha Esa. ${ }^{11}$ Sementara dari perspektif hukum, perkawinan adalah suatu perjanjian hukum (legal agreement) antara seorang laki-laki dan perempuan yang masing-masing telah memenuhi persyaratan yuridis formal. ${ }^{12}$

Perkawinan dalam Islam sebenarnya lebih merupakan suatu akad atau kontrak. ${ }^{13}$ Kontrak itu terlihat dari adanya unsur ijab (tawaran) dan qabul (penerimaan). Untuk memperkuat posisi perempuan dalam perkawinan, maka definisi perkawinan adalah akad yang sangat kuat (mitsaaqan ghaliizan) yang dilakukan secara sadar oleh seorang laki-laki dan seorang perempuan untuk membentuk keluarga yang pelaksanaannya didasarkan pada kerelaan dan kesepakatan kedua belah pihak. ${ }^{14}$ Definisi ini lebih spesifik bila dibandingkan dengan definisi perkawinan dalam KHI pasal 2 yaitu akad yang sangat kuat atau

\footnotetext{
${ }^{11}$ Departemen Agama RI, "Bahan Penyuluhan Hukum; UU No. 7 Tahun 1989 Tentang Peradilan Agama, UU No. 1 Tahun 1974 Tentang Perkawinan, Dan Inpres No. 1 Tahun 1991 Tentang Kompilasi Hukum Islam” (Dirjend Pembinaan Kelembagaan Agama Islam, 2001), 117.

${ }^{12}$ Mulia, Islam Dan Inspirasi Kesetaraan Gender, 190.

${ }^{13}$ Ibid.

14 Departemen Agama RI, Pembaruan Hukum Islam; Counter Legal Draft Kompilasi Hukum Islam (Jakarta: Tim Pengarusutamaan Gender, 2004), 36.
} 
mitsaaqon gholiidha untuk mentaati perintah Allah dan melaksanakannya merupakan ibadah. ${ }^{15}$

Perkawinan dalam dimensi ini tidaklah hanya dilihat dalam sudut pandang legal-spritual, bahkan sebuah sosial engenirng yang mempunyai dampak sosial. Perkawinan bisa menjadi masalah sosial, bahkan bisa juga ia menjadi solusi sosial. Dua sisi ini tergantung bagaimana sudut pandang dalam melihat sebuah perkawinan. Pernikahan usia muda yang marak dilakukan di pedesaan, umumnya sudut pandang kedua belah pihak hanya melihat sebagai sebuah prosesi legalspritual, namun dampak sosial yang akan muncul karena belum matangnya usia bukan menjadi sebuah pertimbangan. Hingga banyak pernikahan usia muda berakhir dengan perceraian. Berdasarkan data pengadilan Agama di beberapa daerah di Indonesia mencatat pasangan yang menikah antara 20-25 tahun 50\% mengalami perceraian.

\section{b. Pencatatan Perkawinan sebagai Rukun}

Pencatatan perkawinan secara konseptual adalah formalisasi spirit dasar ketentuan UUP dan KHI sebagai alat ukur sahnya perkawinan secara yuridisformal. Discourses ini berawal dari kata 'perkawinan harus dicatatkan' membawa implikasi yang berbeda dalam memahaminya. ${ }^{16}$ Bagi yang memahaminya dengan menggunakan pendekatan normatif, maka perkawinan sebagai aktifitas keagamaan dan bagian dari perintah agama. Jadi, perkawinan diposisikan sebagai individual affair, hingga melahirkan pemahaman sahnya perkawinan jika sudah dilakukan berdasarkan hukum agama meskipun tidak dicatatkan. ${ }^{17}$ Komunitas

\footnotetext{
15 RI, "Bahan Penyuluhan Hukum; UU No. 7 Tahun 1989 Tentang Peradilan Agama, UU No. 1 Tahun 1974 Tentang Perkawinan, Dan Inpres No. 1 Tahun 1991 Tentang Kompilasi Hukum Islam," 140.

16 . “. KHI Bab II Pasal 5,” n.d.

${ }^{17}$ M. Yahya Harahap, Informasi Materi Kompilasi Hukum Islam Dan Peralidan Agama Dalam Sistem Hukum Nasional (Jakarta: Logos, 1999), 53.
} 
Islam Indonesia meyakini syarat sahnya perkawinan apabila tersedia lima unsur, yaitu adanya kedua mempelai, ijab qabul, saksi, wali dan mahar. ${ }^{18}$ Disini pencatatan bukan merupakan syarat sahnya perkawinan, karena itu di masyarakat banyak dijumpai perkawinan yang tidak dicatatkan yang dikenal dengan istilah nikah sirri atau kawin di bawah tangan.

Pendekatan yuridis menjadi pilihan Siti Musdah Mulia melihat perkawinan. Perkawinan ditilik dari pendekatan ini merupakan sebuah peristiwa hukum yang mempunyai implikasi positivistik. Sebagai sebuah peristiwa hukum akad pernikahan tidak hanya didasarkan semata-mata atas dasar saling percaya yang diucapkan secara verbalistik, tetapi juga kepercayaan tersebut harus disimbolisasikan dalam sebuah akta tertulis (akta nikah) sebagai bukti yuridis. Berpijak dari paradigma ini redaksi 'harus' menurut Musdah Mulia harus diganti menjadi 'wajib'. Lanjutnya, pencatatan perkawinan harus dimasukkan ke dalam syarat sah pernikahan. ${ }^{19}$

Landasan metodologis untuk memposisikan pencatatan sebagai sebuah keharusan yuridis menggunakan perangkat qias. Yaitu dengan menyamakan peristiwa nikah (furu') sebagai peristiwa hukum yang dianalogikan dengan peristiwa hukum lain seperti jual-beli (buyu') yang memerlukan adanya pencatatan. ${ }^{20}$ Pencatatan dalam jual beli ditempatkan sebagai ketentuan hukumnya (hukm ashal), jadi legal reasoning atau illat hukum antara keduanya adalah samasama sebagai alat untuk menghindari kemungkinan lahirnya sengketa hukum yang lahir dari perikatan.

Perkawinan dalam pandangan normatif sah jika sesuai dengan aturan normativitas agama meskipun tidak tercatat, namun dalam kaca mata yuridis tidak

\footnotetext{
${ }^{18}$ Summa, Hukum Keluarga Islam Di Dunia Islam, 289.

${ }^{19}$ RI, Pembaruan Hukum Islam; Counter Legal Draft Kompilasi Hukum Islam, 37.

20 “QS. Al-Baqarah (2): 282," n.d.
} 
memiliki kekuatan hukum. Perkawinan yang tidak mempunyai kekuatan yuridis berdampak sangat merugikan isteri dan perempuan pada umumnya. Bagi isteri, dampaknya secara hukum adalah tidak dianggap sebagai isteri yang sah karena tidak memiliki akta nikah sebagai bukti otentik. Dampak dominonya, isteri tidak berhak atas nafkah dan warisan suami jika meninggal dunia; isteri tidak berhak terhadap harta gono-gini jika terjadi perceraian karena secara hukum dianggap pernikahan di anggap tidak pernah terjadi (tidak ada terjadi peristiwa hukum). Dan berdampak pula terhadap status keperdataan anak, ia hanya memiliki hubungan perdata dengan ibu dan keluarga ibunya dan tidak mempunyai hubungan keperdataan dengan ayahnya. ${ }^{21}$ Sebagai tindakkan preventif dari kemungkinan lahirnya hal-hal tersebut, landasan metodologis pencatatan perkawinan dapat menggunakan teori saddu dzari'ah yaitu menghambat kemungkinan lahirnya efek negatif dengan berpegang pada dar al-mafasid muqaddamu 'ala jalbi al mashalih ${ }^{22}$ (mencegah dampak negatif didahulukan dari pada menarik kemaslahatan).

Konsekwensi lain dari paradigma yuridis adalah menganggap pernikahan sama dengan transaksi muamalat lainnya seperti jual beli yang tidak mensyaratkan adanya wali dalam bermuamalat jika sudah balig/dewasa. Pernikahan pun bagi perempuan yang sudah dewasa tidak perlu ada wali terlebih proses pencatatan perkawinan sudah mempunyai kekuatan hukum yang mengikat dari ke dua belah pihak. Siti Musdah Mulia melalui paradigma ini menghidupkan lagi perdebatan fikih klasik sah-tidaknya nikah tanpa wali. Namun ia beranggapan dengan tidak menjadikan keberadaan wali sebagai rukun pernikahan maka dapat mengeliminir berbagai tindak kekerasan nikah paksa dengan berdalihkan wali mujbir.

\footnotetext{
21 “UU No. 1 Tahun 1974 Tentang Perkawinan Pasal 42 Dan 43," n.d.

${ }^{22}$ Amir Syarifuddin, Ushul Fiqh, Jilid 2 (Jakarta: Logos, 1999), 144.
} 


\section{c. Poligami}

Islam dikenal satu-satunya agama yang mempertahankan poligami adalah bagian dari agamanya, yang mana agama-agama lain sudah meninggalkannya. Namun, poligami sendiri dikalangan cendikiawan atau ulama Islam masih menjadi sebuah perdebatan. Di Indonesia yang menganut asas monogami terbuka membolehkan suami berpoligami dengan alasan : 1) isteri tidak dapat menjalankan kewajiban sebagai isteri; 2) isteri mendapat cacat badan atau penyakit yang tidak dapat disembuhkan; dan 3) isteri tidak dapat melahirkan keturunan. ${ }^{23}$ Menurut Siti Musdah Mulia ketiga alasan tersebut sama sekali tidak mewadahi tuntunan Allah swt dalam QS. An-Nisa ayat 19 : “... Dan bergaulah dengan mereka (isteri) secara patut. Kemudian, bila kamu tidak menyukai mereka, (maka bersabarlah) karena boleh jadi kamu tidak menyukai mereka, padahal Allah menjadikan padanya kebaikan yang banyak”. Realitas sosiologis di masyarakat menunjukkan bahwa hampir semua poligami yang dilakukan di masyakarat tidak berangkat dari ketiga alasan yang disebutkan itu. Perlu dipertanyakan berapa persen laki-laki yang berpoligami karena ketiga atau salah satu dari alasan tersebut.

Satu-satunya ayat yang selalu dijadikan landasan bagi kebolehan berpoligami adalah an-Nisa ayat 3. Padahal, jika ditelusuri asbab nuzul turunnya ayat itu jelas tidak berbicara dalam konteks perkawinan, melainkan dalam konteks pembicaraan anak yatim. Allah swt ingin menyelamatkan anak yatim dari orangorang yang berkedok perkawinan untuk menguasai harta mereka, serta untuk menghindari perlakuan tidak adil terhadap anak yatim. Maka Allah memberikan solusi agar mengawini perempuan lain yang disukainya sebanyak dua, tiga, atau empat. Itupun jika sanggup berbuat adil -kalau tidak- cukup satu. Dari sini dapat

23 “KHI BAB IX Pasal 57," n.d. 
disimpulkan bahwa prinsip perkawinan dalam Islam adalah monogami, bukan poligami. Oleh karena itu, pelarangan poligami secara mutlak karena poligami dipandang sebagai kejahatan kemanusiaan seperti yang dilakukan di Tunisia.

Siti Musdah Mulia beranggapan apa yang dilakukan di Tunisia dan Turki yang melarang secara mutlak poligami sudah saatnya dilakukan di Indonesia. Ia beralasan begitu banyak problem sosial yang muncul akibat poligami. Di antaranya poligami akan meligitimasi perkawinan di bawah tangan dan terlantarnya para isteri serta anak-anak terutama secara psikologis dan ekonomi. Kristalisasinya adalah poligami lebih banyak mudharat ketimbang manfaatnya. Ini sejalan dengan kaidah ushul fiqh dar'ul mafasid muqaddamun 'ala jalbi mashalih.

Penolakannya terhadap poligami berdasarkan bagaimana berperilaku adil. Apakah adil dalam aspek kualitatif atau kuantitatif. Ia mendasarkan alasan adil ini dengan kerangka pemaknaan ayat al-Qur'an dalam konteks kekinian. Islam tidak membenarkan adanya semua bentuk perkawinan yang di dalamnya ditemukan unsur-unsur kezaliman, kekerasan, ketidakadilan, pelecehan seksual, pemaksaan dan penindasan. ${ }^{24}$

Lebih lanjut, manakala prinsip keadilan ini diterapkan (kualitatif maupun kuantitatif), maka untuk mengidentifikasi nilai-nilai principal dalam kaitannya dengan praktek poligami, semestinya isteri diletakkan sebagai subyek penentu keadilan. ${ }^{25}$ Abdurrahman Wahid (Gus Dur), ${ }^{26}$ menegaskan bahwa para istrilah yang seharusnya mendefinisikan apa yang dimaksud dengan keadilan dalam

\footnotetext{
24 Siti Musdah Mulia, Islam Menggugat Poligami (Jakarta: Gramedia, LKAJ dan The Asia Foundation, 2004), 13.

25 Ibid., 113.

${ }^{26}$ Abdurrahman Wahid, Mark $R$ Woodward, Jalan Baru Islam, Memetakan Paradigma Mutakhir Islam Indonesia (Bandung: Mizan, 1998), 150.
} 
poligami. Dan ia menduga, jika para istri bermusyawarah mengenai perkara ini, maka tidak seorang laki-laki pun yang dapat memenuhi persyaratan keadilan itu.

Persoalan poligami diatur dalam pasal 3, 4, dan 5 undang-undang No. 1 Tahun 1974 tentang perkawinan. Kalau disimak dengan teliti ayat-ayat dalam pasal 3 mengandung inkonsistensi dalam dirinya. Ayat 1 menegaskan azas monogami, sedangkan pada ayat berikutnya memberikan kelonggaran kepada suami untuk poligami walaupun terbatas sampai 4 orang isteri. ${ }^{27}$

Salah satu syarat yang harus dipenuhi suami yang akan mengajukkan poligami adalah persetujuan isteri. Namun ironisnya, pada pasal 59 dalam Kompilasi Hukum Islam dinyatakan: dalam hal isteri tidak mau memberikan persetujuan dan permohonan izin untuk beristeri lebih dari satu orang berdasarkan atas salah satu alasan yang diatur dalam pasal 55 ayat 2 dan 57, pada pasal 59 disebutkan Pengadilan Agama dapat menetapkan tentang pemberian izin setelah memeriksa dan mendengarkan isteri yang bersangkutan di persidangan Pengadilan Agama, dan terhadap penetapan ini isteri atau suami dapat mengajukan banding atau kasasi.

Pasal ini jelas mengindikasikan betapa lemahnya posisi isteri. Sebab, manakala isteri menolak memberikan persetujuannya, Pengadilan Agama dengan serta merta mengambil alih kedudukannya sebagai pemberi izin, meskipun di akhir pasal tersebut ada klausul yang memberikan kesempatan pada isteri untuk mengajukan banding.

Alasan-alasan yang dipakai Pengadilan Agama memberikan izin kepada suami berpoligami: 1) isteri tidak dapat menjalankan kewajiban sebagai isteri; 2) isteri mendapat cacat badan atau penyakit yang tidak dapat disembuhkan; dan 3) isteri tidak dapat melahirkan keturunan. Ketiga alasan dalam UUP tersebut sama

${ }^{27}$ Mulia, Islam Menggugat Poligami, 193. 
sekali tidak mewadahi tuntutan Allah swt dalam surat an-Nisa ayat 19: dan bergaullah dengan mereka (isteri) secara patut, kemudian bila kamu tidak menyukai mereka, (maka bersabarlah) karena boleh jadi kamu tidak menyukai sesuatu, padahal Allah menjadikan padanya kebaikan yang banyak.

Relitas sosiologis di masyarakat menunjukkan bahwa hampir semua poligami yang dilakukan di masyarakat tidak berangkat dari ketiga alasan yang disebutkan itu. Perlu dipertanyakan berapa persen laki-laki yang berpoligami karena alasan isteri tidak menjalankan kewajibannya, atau karena isteri mendapat cacat badan, atau karena isteri mandul? Semua alasan yang membolehkan suami poligami hanya dilihat dari perspektif kepentingan suami tanpa mempertimbangkan perspektif kepentingan perempuan. Tidak pernah dipertimbangkan, misalnya andai kata suami tidak mampu menjalankan kewajibannya sebagai suami, atau suami mendapat mendapat cacat atau penyakit, atau suami mandul apakah pengadilan agama juga akan memberikan izin kepada isteri untuk menikah lagi?

Musdah Mulia mengusulkan pelarangan mutlak poligami seperti yang dilakukan di Tunisia. Tunisia melarang poligami dengan alasan institusi perbudakan dan poligami hanya boleh pada masa perkembangan, tetapi dilarang setelah menjadi masyarakat berbudaya. ${ }^{28}$ Syarat mutlak bolehnya poligami adalah kemampuan berlaku adil pada isteri, sementara fakta sejarah membuktikan hanya Nabi yang mampu berlaku adil terhadap isteri-isterinya. Sejalan dengan Tunisia, Turki merupakan negara muslim pertama yang melarang poligami secara mutlak melalui UU Civil Turki tahun $1926 .{ }^{29}$ Untuk konteks Indonesia, alasan yang

\footnotetext{
${ }^{28}$ John L. Esposito, Women in Muslim Family Law (New York: Syracus University Press, 1982), 92.

${ }^{29}$ Khoiruddin Nasution, Status Wanita Di Asia Tenggara Studi Terhadap Perundang-Undangan Perkawinan Muslim Kontemporer Di Indonesia Dan Malaysia (Jakarta: INIS, 2002), 117.
} 
dipakai untuk melarang poligami secara mutlak adalah begitu banyak problem sosial yang muncul akibat poligami. Di antaranya poligami melegitimasi perkawinan di bawah tangan, tingginya kasus perkawinan di bawah tangan, tingginya kasus perkawinan anak-anak, menyebabkan tingginya kasus domestic violence dan terlantarnya para isteri dan anak-anak, terutama secara psikologis dan ekonomi.

\section{d. Usia Perkawinan}

Batas minimal usia nikah dalam UUP sebagaimana dinyatakan dalam pasal 7 ayat 1 adalah 19 tahun bagi laki-laki dan 16 tahun bagi perempuan. ${ }^{30}$ Penetapan batas usia bagi perempuan yang lebih rendah dari laki-laki pada substansinya mempertegaskan subordinasi perempuan (isteri) terhadap laki-laki (suami). Batasan usia minimal pada umur 16 tahun bagi perempuan sesungguhnya bertentangan dengan isi UU no. 4 tahun 1979 tentang Kesejahteraan Anak. Pasal 1 ayat 2 dari UU tersebut menjelaskan: anak adalah seseorang yang belum mencapai umur 21 tahun dan belum pernah kawin. Penetapan itu juga bertentangan dengan isi Konvensi Internasional mengenai Hak Anak yang diratifikasi Indonesia pada tahun 1990. Konvensi tersebut menegaskan batas usia anak adalah 18 tahun. Melegalkan perkawinan bagi perempuan umur 16 tahun berarti pemerintah melegitimasi perkawinan anak-anak. ${ }^{31}$

Umur perkawinan di Syiria, bukan hanya batas usia terendah untuk menikah yang diatur, melainkan juga selisih umur antara laki-laki dan perempuan yang akan menikah. Jika perbedaan usia di antara mereka terlalu jauh, pengadilan

\footnotetext{
${ }^{30}$ Departemen Agama RI, "UUP Pasal 7 Ayat 1 Dalam Departemen Agama RI, Bahan Penyuluhan Hukum; UU No. 7 Tahun 1989 Tentang Peradilan Agama, UU No. 1 Tahun 1974 Tentang Perkawinan, Dan Inpres No. 1 Tahun 1991 Tentang Kompilasi Hukum Islam" (Dirjend Pembinaan Kelembagaan Agama Islam, 2001), 119.

${ }^{31}$ RI, Pembaruan Hukum Islam; Counter Legal Draft Kompilasi Hukum Islam, 37.
} 
dapat melarang perkawinan itu. Demikian pula di Yordania, perkawinan dilarang jika selisih umur kedua pihak yang akan menikah lebih dari dua puluh tahun, kecuali ada izin khusus dari pengadilan. Tujuan pemerintah di kedua negara tersebut mengatur selisih umur antara kedua calon mempelai adalah semata-mata untuk memproteksi warganya dari tindakan eksploitasi dan pemerasan. Mengingat posisi umur sangat urgent bagi mempelai perkawinan, maka dalam rancangan CLD ditawarkan usia calon suami atau isteri minimal 19 tahun. ${ }^{32}$ Dalam usia tersebut kematangan berpikir serta kedewasaan secara fisik dan psikologis keduanya sudah terpenuhi, sedangkan usia di bawah itu dimungkinkan kemampuan mengendalikan pikiran mereka sendiri terlalu rendah. ${ }^{33}$

\section{e. Kedudukan Suami-Isteri}

Undang-undang Perkawinan mengatur kedudukan suami-isteri sebagai hak dan kedudukan isteri adalah seimbang dengan hak dan kedudukan suami dalam kehidupan rumah tangga dan pergaulan hidup bersama dalam masyarakat. ${ }^{34}$ Selanjutnya masing-masing pihak berhak untuk melakukan perbuatan hukum dan suami adalah kepala keluarga dan isteri ibu rumah tangga. ${ }^{35}$ Kandungan isi kedudukan suami-istri dalam UUP tersebut tampak inkonsistensi, saling bertentangan satu sama lain.

Dalam dua ayat pertama dinyatakan kedudukan suami istri seimbang, baik dalam kehidupan di rumah tangga maupun di masyarakat, tetapi bagaimana mungkin dikatakan seimbang sementara pada ayat berikutnya kedudukan suami sudah dipatok sebagai kepala keluarga. Penggunaan kata kepala dalam menjelaskan kedudukan suami mengandung konotasi kekuasaan dan sangat

\footnotetext{
32 Ibid.

${ }^{33}$ Khoiruddin Nasution, Fazlur Rahman Tentang Wanita (Yogyakarta: Tazzafa, 2002), 229.

34 “UUP Pasal 31 Ayat 2 Dan 3," n.d., 119.

${ }^{35}$ Ibid.
} 
terkesan otoriter sehingga tidak salah kalau masyarakat awam memandang suami identik dengan penguasa di ruang lingkup keluarga. ${ }^{36}$ Implikasi dari pemahaman ini di masyarakat, antara lain suami sah saja berkuasa secara otoriter di rumah tangga, termasuk mewajibkan istri melakukan seluruh tugas di rumah tangga dan melayani seluruh keperluan dan kebutuhan dirinya lahir batin.

Umumnya pandangan streotip suami sebagai kepala keluarga didasarkan kepada firman Allah swt dalam an-Nisa ayat 34 ar-rijal qawwamuna 'ala nisa yang selalu diterjemahkan laki-laki adalah pemimpin bagi wanita. Berkaitan dengan ayat tersebut, pertama harus dijelaskan makna qawwam. Kalaupun itu dimaknai dengan pemimpin maka pemimpin yang dikehendaki dalam Islam adalah pemimpin yang demokratis, penuh kasih sayang dan pengertian, bukan pemimpin yang otoriter, memaksa dan sewenang wenang. Kedua, harus dipahami bahwa posisi qawwam bagi suami tidaklah otomatis, melainkan sangat tergantung pada dua syarat yang diterapkan pada penghujung ayat, yakni memiliki kualitas yang lebih dari pada istrinya, dan kualitas dimaksud bisa bermakna fisik, moral, intelektual, dan finansial; serta syarat telah menunaikan kewajibannya memberi nafkah kepada keluarga. Itulah sebabnya dalam ayat itu kata rijal menggunakan alif lam yang dalam kaidah bahasa Arab berarti sesuatu yang definitif atau tertentu. Artinya, tidak menunjuk kepada semua suami, melainkan hanya suami tertentu yang memiliki dua kualifikasi tersebut. Musdah Mulia menawarkan ayat ayat 3 dalam pasal tersebut hilangkan karena memberikan pemahaan stereotif suami sebagai kepala keluarga.

Yang perlu ditegaskan dalam UUP dua hal. Pertama, bahwa hubungan suami-isteri hendaknya dibangun di atas landasan kesetaraan sesuai dengan tuntutan Alquran hunna libasun lakum wa antum libasun lahunna (istri

${ }^{36}$ Mulia, Islam Menggugat Poligami, 198. 
merupakan pelindung bagi suami dan sebaliknya, suami pelindung bagi istri). ${ }^{37}$ Kedua, bahwa hubungan suami-istri hendaknya didasarkan pada nilai-nilai akhlak yang mulia sesuai ayat wa'asyiruhunna bil ma'ruf (pergaulilah istrimu dengan cara yang patut). ${ }^{38}$

\section{f. Hak dan Kewajiban Suami-Istri}

Ketentuan mengenai hal tersebut diatur secara tegas dalam pasal 34 ayat 1 bahwa suami wajib melindungi istrinya dan memberikan segala keperluan hidup berumahtangga sesuai dengan kemampuannya; istri wajib mengatur urusan rumah sebaik-baiknya; jika suami atau istri melalaikan kewajiban masing-masing dapat mengajukan gugatan kepada pengadilan. ${ }^{39}$ Pasal-pasal tersebut sangat jelas mengindikasikan adanya pengukuhan pembagian dan pembakuan peran perempuan berdasarkan jenis kelamin dan sekaligus mengukuhkan domestikasi perempuan. Domestikasi ini mengarahkan kepada upaya penjinakan, segregasi ruang, dan depolitisasi perempuan.

Kewajiban istri di masyarakat dipahami harus berbakti kepada suami seolah tanpa batas sehingga muncul ungkapan klise kewajiban istri adalah melayani suami sejak mata suami terbit sampai mata suami terbenam. Ketentuan bahwa istri wajib mengatur urusan rumah sebaik-baiknya membenarkan anggapan streotip masyarakat bahwa tempat perempuan yang layak hanyalah di rumah, yakni hanya sebatas kasur, sumur, dan dapur. Bahwa hanya istrilah yang memikul kewajiban menyelesaikan semua tugas-tugas di rumah tangga, sebaliknya suami bebas dari kewajiban demikian. Kalau istri keluar rumah dipandang tidak terhormat karena telah melalaikan kewajibannya.

\footnotetext{
37 “QS. Al-Baqarah (2): 187,” n.d.

38 “QS. Al-Nisa (4): 19," n.d.

39 "UUP Pasal 34 Ayat 1 Sampai 3,” n.d.
} 
Implikasinya dalam undang-undang ketenagakerjaan, kalau istri bekerja mencari nafkah di luar rumah, pekerjaannya itu hanya dinilai sebagai pekerjaan tambahan dan karenanya ia dibayar sebagai pencari nafkah tambahan, bukan pencari nafkah utama. Akibatnya, pekerjaan perempuan selalu digolongkan dalam status pekerja lajang, meskipun secara riil memiliki suami dan anak. Istri tidak menerima tunjangan untuk suami dan anak-anak sebagaimana yang diterima oleh rekan kerjanya yang laki-laki. Padahal, sejumlah penelitian menjelaskan bahwa tidak sedikit dari perempuan yang bekerja itu justru merupakan pencari nafkah utama di dalam keluarga, di pundak merekalah seluruh anggota keluarga, termasuk suami menggantungkan biaya hidup.

\section{E. Kesimpulan}

Berawal dari teosentris ke antrosentris adalah gaya berpikir Siti Musdah Mulia. Ia melihat manusia sebagai subyek sosial bukan obyek. Karena itu, interpretasi teks-teks yang dilakukannya selalu menempatkan manusia sebagai subyek, ini terlihat dalam ide-idenya dalam merekonstrukisi struktur dalam beberapa masalah dalam UUP ataupun KHI. Ia melihat aspek sosial dalam UUP ataupun KHI harus diletakkan didepan agar rasa keadilan dapat terayomi bagi semua pihak yang terlibat dalam subyek hukum tersebut.

Kultur Indonesia yang silih berganti diwarnai berbagai kekerasan dalam keluarga memerlukan perubahan struktur hukum. Perubahan struktur hukum inilah yang nantinya membawa kepada perubahan kultur. Misalkan perubahan dalam struktur perundang-udangan dalam hal pencatatan perkawinan, tentu kultur nikah sirri, pernikahan di bawah umur sedikit banyak akan berkurang. Tentunya kultur pernikahan yang legal serta yang membawa kepada kematangan berumah tangga akan tercipta. 
Alhasil, perubahan merupakan sesuatu yang mesti dilakukan dalam berbagai hal guna mengiringi perubahan waktu dan jaman yang selalu berputar. Begitu pula perubahan dalam hukum keluarga adalah sebuah keniscayaan jika produk yang ada sudah tidak dapat menjadi payung hukum membendung lajunya berbagai kasus perselingkuhan dan perceraian yang disebabkan lemahya payung hukum yang berlaku.

\section{Daftar Pustaka}

. “. KHI Bab II Pasal 5,” n.d.

Esposito, John L. Women in Muslim Family Law. New York: Syracus University Press, 1982.

Harahap, M. Yahya. Informasi Materi Kompilasi Hukum Islam Dan Peralidan Agama Dalam Sistem Hukum Nasional. Jakarta: Logos, 1999.

Isjawara, F. Pengantar Ilmu Politik. Jakarta: Bina Cipta, 1992.

“KHI BAB IX Pasal 57," n.d.

Mulia, Siti Musdah. Islam Dan Inspirasi Kesetaraan Gender. Yogyakarta: Kibar Press, 2007.

. Islam Menggugat Poligami. Jakarta: Gramedia, LKAJ dan The Asia Foundation, 2004.

- Muslimah Reformasi; Perempuan Pembaru Keagamaan. Bandung: Mizan, 2005.

Nasution, Khoiruddin. Fazlur Rahman Tentang Wanita. Yogyakarta: Tazzafa, 2002.

—. Status Wanita Di Asia Tenggara Studi Terhadap Perundang-Undangan Perkawinan Muslim Kontemporer Di Indonesia Dan Malaysia. Jakarta: INIS, 2002.

“QS. Al-Baqarah (2): 187," n.d.

"QS. Al-Baqarah (2): 282," n.d.

"QS. Al-Nisa (4): 19," n.d.

RI, Departemen Agama. "Bahan Penyuluhan Hukum; UU No. 7 Tahun 1989 Tentang Peradilan Agama, UU No. 1 Tahun 1974 Tentang Perkawinan, Dan Inpres No. 1 Tahun 1991 Tentang Kompilasi Hukum Islam.” Dirjend Pembinaan Kelembagaan Agama Islam, 2001.

- Pembaruan Hukum Islam; Counter Legal Draft Kompilasi Hukum Islam. Jakarta: Tim Pengarusutamaan Gender, 2004. 
. "UUP Pasal 7 Ayat 1 Dalam Departemen Agama RI, Bahan Penyuluhan Hukum; UU No. 7 Tahun 1989 Tentang Peradilan Agama, UU No. 1 Tahun 1974 Tentang Perkawinan, Dan Inpres No. 1 Tahun 1991 Tentang Kompilasi Hukum Islam.” Dirjend Pembinaan Kelembagaan Agama Islam, 2001.

Ridwan. Membongkar Fiqh Negara: Wacana Keadilan Gender Dalam Hukum Keluarga Islam. Yogyakarta: Unggun Religi, 2005.

Saridjo, Marwan. Cak Nur: Di Antara Sarung Dan Dasi Dan Musdah Mulia Tetap Berjilbab. Jakarta: Yayasan Ngali Aksara dan Penamadani, 2005.

Setiawan, Beni. "Menggugat Poligami; Studi Atas Pemikiran Musdah Mulia." ElMashlahah 3, no. 2 (2013).

-. "Menggugat Poligami; Studi Atas Pemikiran Musdah Mulia." ElMashlahah 3, no. 2 (2013).

"Siti Musdah Mulia," n.d.

http://www.prismajurnal.com/biodata.php?id=2ac22c0e-53a0-11e3-a6cc$429 \mathrm{e} 1 \mathrm{~b} 0 \mathrm{bc} 2 \mathrm{fa}$.

Summa, Muhammad Amin. Hukum Keluarga Islam Di Dunia Islam. Jakarta: Rajawali Pers, 2004.

Syarifuddin, Amir. Ushul Fiqh, Jilid 2. Jakarta: Logos, 1999.

UNICEF. Kemajuan Yang Tertunda: Analisis Data Perkawinan Usia Anak Di Indonesia. Jakarta: Badan Pusat Statistik, 2015.

“UU No. 1 Tahun 1974 Tentang Perkawinan Pasal 42 Dan 43," n.d.

"UUP Pasal 31 Ayat 2 Dan 3," n.d.

"UUP Pasal 34 Ayat 1 Sampai 3," n.d.

Wahid, Abdurrahman. Mark $R$ Woodward, Jalan Baru Islam, Memetakan Paradigma Mutakhir Islam Indonesia. Bandung: Mizan, 1998. 